Misr J. Ag. Eng., 26(3): 1068 - 1080

FARM MACHINERY AND POWER

\title{
DEVELOPMENT AND TEST ATTACHMENTS TO THE TANGENTIAL FLOW THRESHER TO SUIT CARAWAY CROP THRESHING
}

\author{
Radwan, G.G; R.G. Salim and A.S. Al-Ashry
}

\begin{abstract}
The aim of this work is to develop and construct attachments to the local thresher to study the feasibility of using local cereal threshing machine for threshing caraway crop. The auxiliary parts attached to the thresher may maximize thresher exploitation. The thresher with attachments was tested at different operating conditions, at rotor speeds (500, 560, 630, and 700 rpm, moisture contents of caraway straw 10.36, 11.84 and 13.72 $\%$. Air speeds on sieves $(4.8,5.7$ and $6.8 \mathrm{~m} / \mathrm{s})$ were also tested. Some of factors were fixed such as, hole diameter of sieves was $3 \mathrm{~mm}$, feed rate was $540 \mathrm{~kg} / \mathrm{h}$ and concave clearance was $15 \mathrm{~mm}$. The experiments were carried out in north Egypt (Tafhna - El-Azab, Zefta, Garbia governorate) during the winter season of 2007 on Caraway crop. The obtained results show the local threshing machine can be successfully used for threshing caraway under the following conditions: seed moisture content of 11.84 $\%$, drum speed of $500 \mathrm{rpm}$ and air speed of $4.8 \mathrm{~m} / \mathrm{s}$ resulting seed losses of $2.2 \%$, threshing efficiency of $73.7 \%$, and criterion energy consumed $29.04 \mathrm{~kW} . \mathrm{h} / \mathrm{ton}$.
\end{abstract}

\section{INTRODUCTION}

araway is a biennial, with smooth, furrowed stems growing 1.5 to 2 feet high, hearing finely cut leaves, and umbels of white flowers which blossom in June. The fruits which are popularly and incorrectly called seeds - and which correspond in general character to those of the other plants of this large family, are laterally compressed, somewhat horny and translucent, slightly curved, and marked with five distinct, pale ridges. They evolve a pleasant, aromatic odour when bruised, and have an agreeable taste. The leaves possess similar properties and afford oil identical with that of the fruit.

Agric. Eng. Res. Inst. Dokki, Giza. 
The tender leaves in spring have been boiled in soup, to give it an aromatic flavor. Threshing of caraway manually where more labors for collecting and re-threshing is required. Under Egyptian conditions caraway is considered valuable byproduct for medicine plant. So this study aimed to break straw into chaff directly while threshing operation in order to save the time, effort and cost. The present varieties of caraway have shattering seeds which may lead to considerable yield losses. If through breeding the character non-shattering seed could be added to the existing favorable properties, the harvesting methods could be simplified essentially. This would be of real advantage in the areas of cultivation.

Omar (1995) concluded that, the unthreshed grains decreased while the damage grain and cleaning efficiency increased with increasing drum speed from 400 to $600 \mathrm{rpm}$. The optimum threshing dry pea can be obtained at $600 \mathrm{rpm}$.

El-Behery et al., (2000) tested El-Shams rice thresher as dual purpose machine to obtain seeds and stalks from flax crop. The threshing was performed using a range of drum speeds, feed crop rates and the lengths of conveyor chain tension at four different levels of capsule moisture contents. Results of the experiments indicated that for optimum performance the threshing drum speed, feed rate and length of conveyor tension should be approximately $31.43 \mathrm{~m} / \mathrm{s}, 20 \mathrm{~kg} / \mathrm{min}$ and $48 \mathrm{~mm}$, respectively at $18.45 \%$ moisture content of capsules. Seed damage was not of an economically importance level (1.78\%). The optimum fuel consumption values were $3.7 \mathrm{liter} / \mathrm{h}$ and 3.08 liter/ton, at $31.43 \mathrm{~m} / \mathrm{s}$ drum speed and $20 \mathrm{~kg} /$ minute feed rate. The average cost of flax threshing was 16.23 L.E/ton compared with 50 L.E/ton for manual threshing.

Bansal and Dahiya (2001) studied the effect of threshing techniques on quality of sunflower seeds. It has been observed that speed loss was minimum at high moisture content of $34.9 \%$ and cylinder speed of 6.5 to $>7.14 \mathrm{~m} / \mathrm{sec}$ for feed rate of $2000 \mathrm{~kg} / \mathrm{h}$. As feed rate increased high than $2000 \mathrm{~kg} / \mathrm{h}$ threshing efficiency decreased.

Chandrakanthappa et al. (2001) used a rasp-bar type multi-crop thresher to thresh finger millet (Eleusine coracana). The best results of threshing efficiency of $79.61 \%$ and mechanical damage of $2.95 \%$ were obtained at $4 \mathrm{~mm}$ concave clearance, $1000 \mathrm{rpm}(1200 \mathrm{~m} / \mathrm{min})$ thresher drum speed and grain moisture content of $10 \%$ wet basis. 
Awady et al. (2003) showed that cleaning efficiency and total losses were positively affected by air speed and sieve tilt angle, but purity was negatively affected by moisture content and feed rate. The total losses were negatively affected by moisture content and feed rate. Purity increased when using round-hole sieve compared with slotted sieve. The optimum performance of cleaning rice crop was at air speed of $4 \mathrm{~m} / \mathrm{sec}$, moisture content of $18 \%$, sieve tilt angle of 2 degree, round-shape sieve and feed rate of $1200 \mathrm{~kg} / \mathrm{h}$. Purity of these conditions was $98.98 \%$ and a total loss was $0.21 \%$.

Johnson (2003) revealed that the effect of thresher setting and grain damage-sample purity: damage comes from impact, crushing and shearing of grain that takes place not only in the thresher but in grain handling equipment as well. Augers are not the best way to move grain if damage is to be kept small. The dominant machine setting affecting grain damage is cylinder or rotor speed, but other settings are relevant. Grain damage tends to increase with thresher speed, so try to operate at the lowest cylinder or rotor speed that will shell the most grain with acceptable levels damage to grain (with acceptable loss levels). Damage to grain can start right at the head it self. Corn is more susceptible to damage at higher moisture content therefore, harvesting at $15 \%$ to $22 \%$ kernel moisture level is advantageous.

Metwalli et al., (2003) mentioned that thresher reduced energy by $39.84 \%$, time by $99.7 \%$, losses by $86.91 \%$. About $42.96 \%$ grain losses was saved compared with manual threshing.

Tsujimoto et al., (2006) showed that, the introduced Turkish thresher has become widespread among small-scale farmers in Morocco. However, the length of straw for appropriate for animal feed could not be produced by the Turkish thresher. Therefore, an inlet and an outlet for wheat and barley straw were installed in the threshing drum. In addition, the threshing drum was adapted to a screw-type tooth arrangement. Trial manufacture was then done in order to secure the appropriate length of straw. The result of the earlier performance test of the Turkish thresher showed that more than $90 \%$ of the straw was cut into small pieces of less that $10 \mathrm{~cm}$ and was therefore of no value for feed. However, the results of the improved screw type threshing drum showed a rate of straw loss of 
only $9.0 \%$ for "Merchouch" wheat and $10.3 \%$ for "Beldi" barley. It was therefore demonstrated that the improved screw-type threshing drum was able to produce a reasonable length of straw for feed. The objectives of this study are to develop and evaluate the performance of the local thresher to be suitable for caraway crop threshing.

\section{MATERIALS AND METHODS}

This study was conducted to develop local thresher (El-Shams) type, tangential axial - flow cereal crops thresher, to be suitable for threshing of caraway crop.

\section{Materials:}

\section{The utilized local thresher machine:}

The local thresher (El-Shams) type, model tangential axial-flow consists of group of parts as shown in fig. 1. It has gross dimensions $67.5 \mathrm{~cm}$ drum diameter, $118 \mathrm{~cm}$ drum length, drum speed ranged from 450 to $850 \mathrm{rpm}$, number of spike tooth knives of 44 (29 cm long and $0.8 \mathrm{~cm}$ thickness) and the power was transmitted from tractor (Universal 650-M, Romania, Four-stroke diesel engine, $55.93 \mathrm{~kW}(75 \mathrm{Hp})$, and $1440 \mathrm{rpm})$ to thresher machine by a pulley and belt. The type of straw racks is fans, vibrators, and sieves.

The local thresher after development, the following parts were fabricated and assembled for the proposed development. 1) Replacing the sieve by another sieve of $3 \mathrm{~mm}$ holes diameter. 2) Change the pulleys and angle of fan to give low rotor and fan speed. This modification aimed to increase the efficiency, maximizing the benefiting of the developed local thresher, saving the time and effort, decreasing power requirements and minimizing the high direct cost. The performance of the modified thresher will be influenced by rotor speed, moisture content of caraway straw and air speed. 


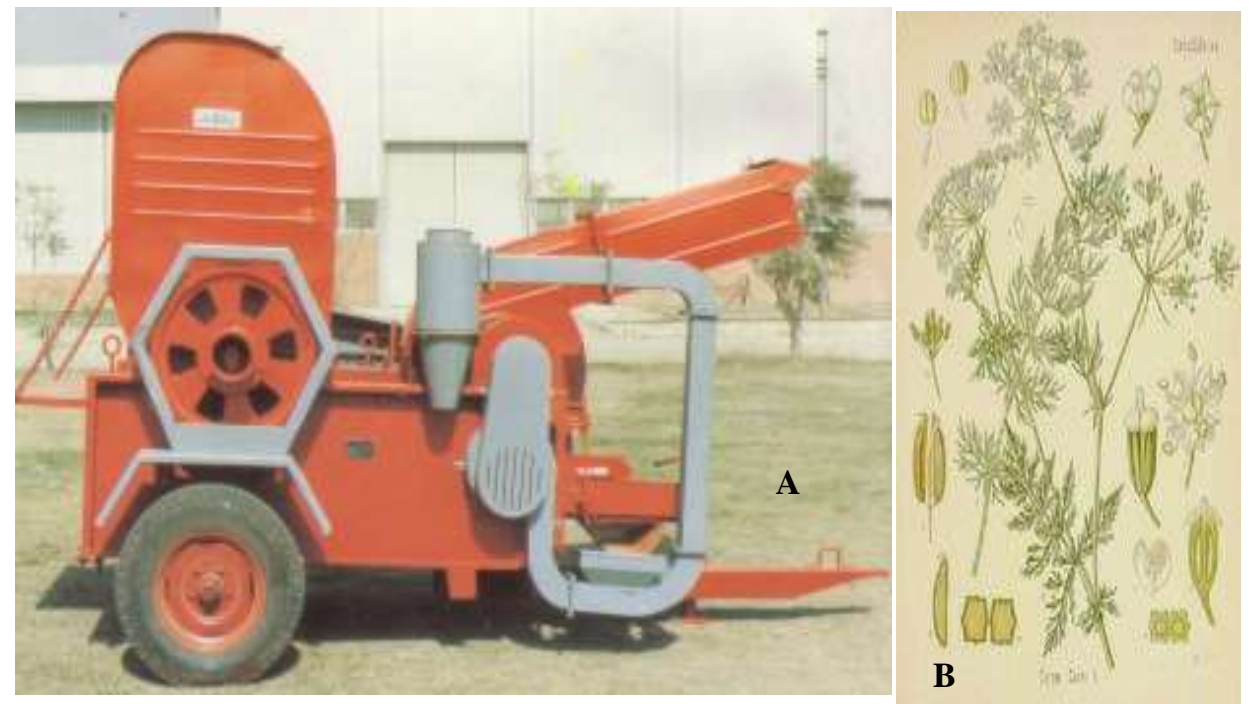

Fig. 1: A, Photograph for modified thresher (EL-SHAMS) type. B, Caraway plant

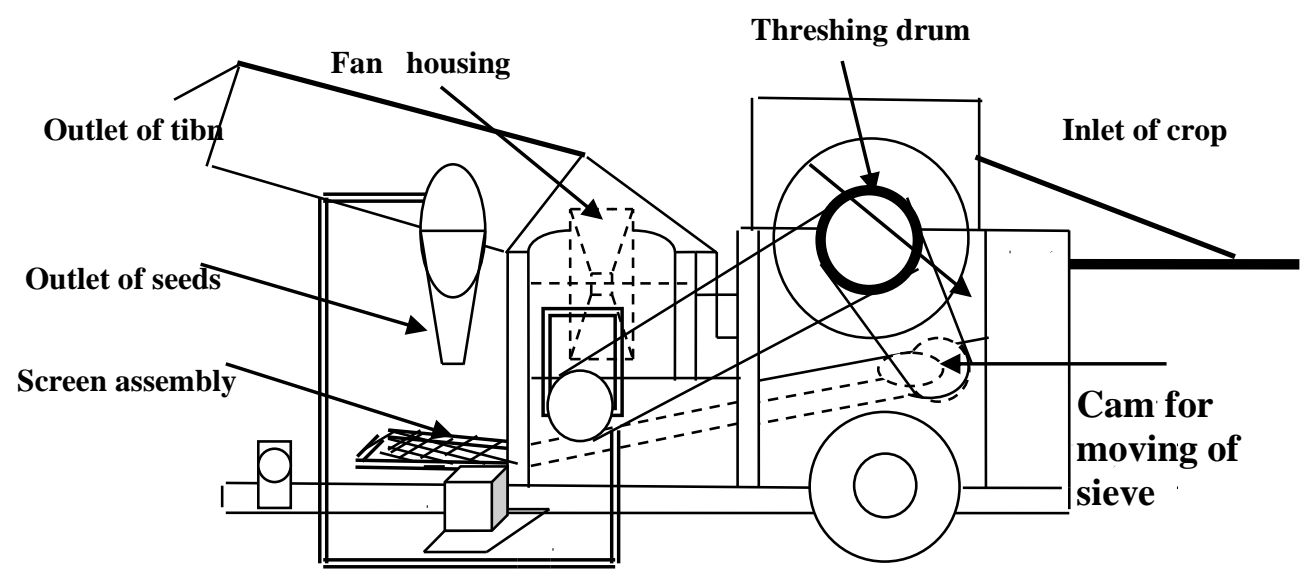

Fig. 2: Schematic diagram for modified thresher (EL-SHAMS) type 


\section{Field experiments}

The machine was tested at concave hole diameter $15 \mathrm{~mm}$, cleaning sieves holes of $3 \mathrm{~mm}$ and tilt angle of threshing spikes $90^{\circ}$ on tangential axis for drum in threshing zone.

\section{Variable parameters}

1- Rotor speed 500, 560, 630 and $700 \mathrm{rpm}$ named $\mathrm{R}_{1}, \mathrm{R}_{2}, \mathrm{R}_{3}$ and $\mathrm{R}_{4}$ respectively,

2- The moisture content of straw was measured to obtain three levels of 10.36, 11.84 and $13.72 \%$ named $\mathrm{Mc}_{1}, \mathrm{Mc}_{2}$ and $\mathrm{Mc}_{3}$ respectively.

3- Air speed was adjusted to attained three levels $4.8,5.7$ and $6.8 \mathrm{~m} / \mathrm{s}$ ) named $S_{1}, S_{2}$, and $S_{3}$ respectively.

\section{Experimental measurements:}

To study influence of the variable parameters on threshing efficiency, the grain losses and power requirement, the following measurements were carried. The tests were repeated three times for more accurate average data.

\section{1- Threshing efficiency and seed losses:}

Threshing efficiency and seed losses were calculated by the following formulas:

Threshing efficiency $\%=\frac{\text { Mass of threshed seeds }}{\text { Total mass of seeds }} \times 100---(1)$

$$
\text { Seed losses } \%=\frac{\text { Mass of seed losses in the straw }}{\text { Total mass of seeds }}
$$

\section{Determination of fuel consumption:}

Fuel consumption was determined by measuring the volume consumed fuel during threshing.

4. Required power $=3.163 *$ fuel cons. $(\mathrm{L} / \mathrm{h})$. $\mathrm{kW}$ ( Empapy 1985)

$$
\text { Required power }(\mathrm{kW})
$$

5- Energy requirement $=$ $\times \mathrm{kW} . \mathrm{h} / \mathrm{ton}$

Machien productivity (ton/h) 


\section{RESULTS AND DISCUSSION}

\section{1- Effect of different tested factors on Threshing efficiency:}

Data plotted in Fig. (3) Show the effect of rotor speed on the threshing efficiency. Increasing rotor speed tends to increase the threshing efficiency. At air speed $(4.8 \mathrm{~m} / \mathrm{s})$ and moisture content $(10.36 \%)$, increasing rotor speed from 500 to $700 \mathrm{rpm}$ increased the threshing efficiency from 70.2 to $73.7 \%$. The rotor speed that increase threshing efficiency $700 \mathrm{rpm}$. Higher rotor speed tends to increase threshing efficiency. Threshing efficiency had a direct relationship with the rotor speed and had indirect effect with air speed. This may be because of increasing air speed led to dragging more grain in chaff. The optimum threshing efficiency achieved at $11.84 \%$ straw moisture content and the lowest air speed $4.8 \mathrm{~m} / \mathrm{s}$.

The following equation was obtained through a multiple regression analysis to illustrate the dependency of independent variables on the threshing efficiency.

T. E. $=57.98+0.0016$ R. S. +0.86 Mc - 0.89 A.S

Where:

T. E. $=$ Threshing efficiency $(\%)$.

R. S. = Rotor speed (rpm).

Mc $=$ Moisture content $(\%)$

A. $\mathrm{S} .=$ Air speed $(\mathrm{m} / \mathrm{s})$

$$
\mathrm{R}-\mathrm{Sq}=91.5 \%
$$

\section{2- Effect of different tested factors on seed losses efficiency:}

Data in Fig. (4) show the effect of rotor speed on the seed losses. At air speed $4.8 \mathrm{~m} / \mathrm{s}$ and straw moisture content $10.36 \%$ rotor speed range from 500 to $700 \mathrm{rpm}$; seed losses increased from 2.2 to $2.7 \%$, which is direct relationship between rotor speed and seed losses. This indicates that optimum rotor speed was the $(500 \mathrm{rpm})$. The high seed losses may be attributed to the excessive load of the threshed material (straw and seeds) on the shoe sieves. Excessive load occurred by decreasing rotor speed which cause slow motion of the threshed material. Due slow motion some seeds which did not have the chance to go penetrate the threshed material 
layers and holes of the shoe sieve. The lowest seed losses obtained at 500 rpm rotor speed, 11.84 straw moisture content and $4.8 \mathrm{~m} / \mathrm{s}$ air speed.

A multiple regression analysis was carried out taking threshing efficiency, as dependent variable and rotor speed, air speed and straw moisture content as independent variables.

S. L. $=-0.0016+0.024$ R.S. $+0.0033 \mathrm{Mc}+0.12$ A. S.

Where:

S. L. $=$ Seed losses $(\%)$.

R. S. = Rotor speed (rpm).

$\mathrm{Mc}=$ Moisture content $(\%)$

A. $\mathrm{S} .=$ Air speed $(\mathrm{m} / \mathrm{s})$

$$
\mathrm{R}-\mathrm{Sq}=90.7 \%
$$



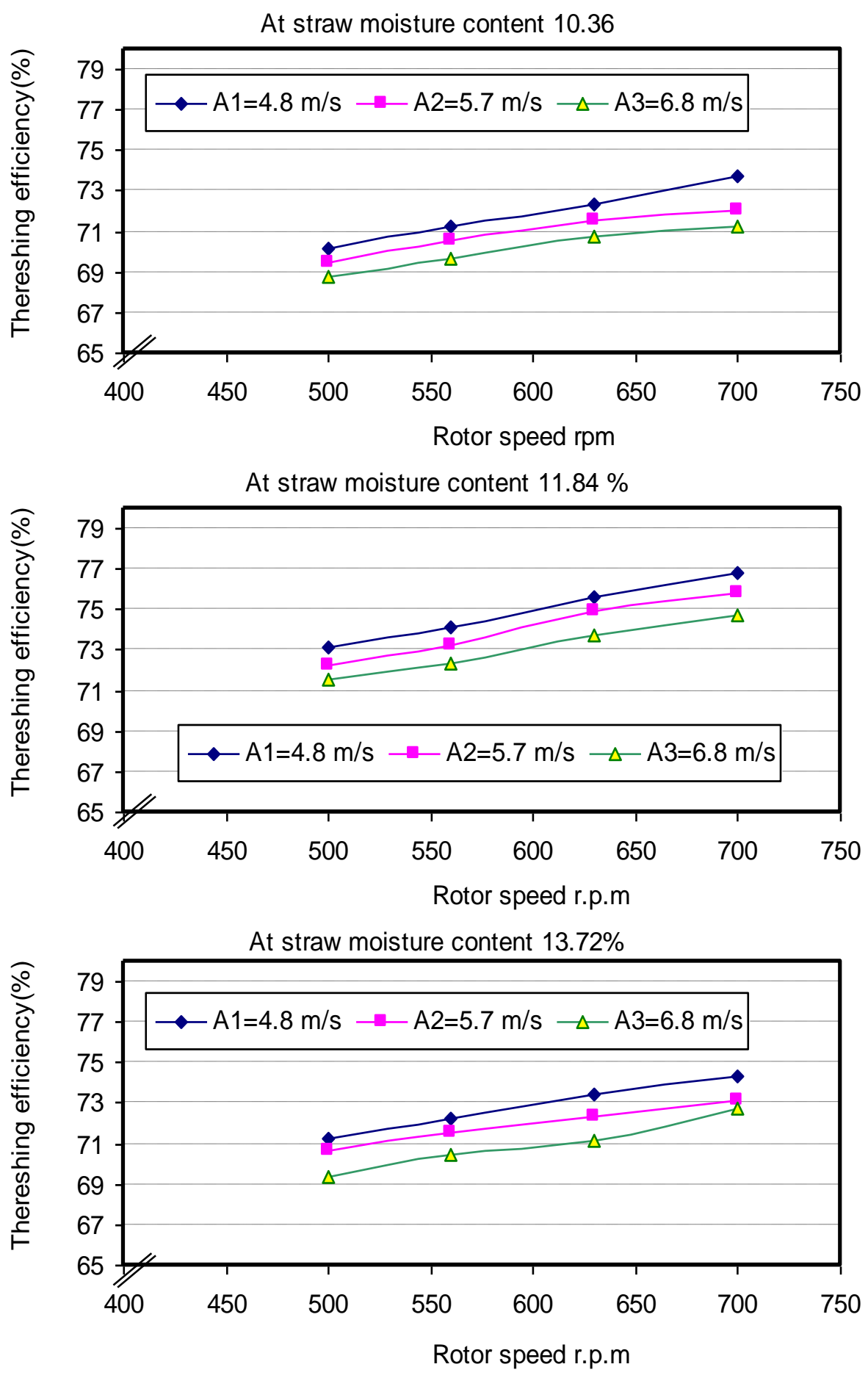

Fig.3. Effect of the tested factors on the threshing efficiency. 

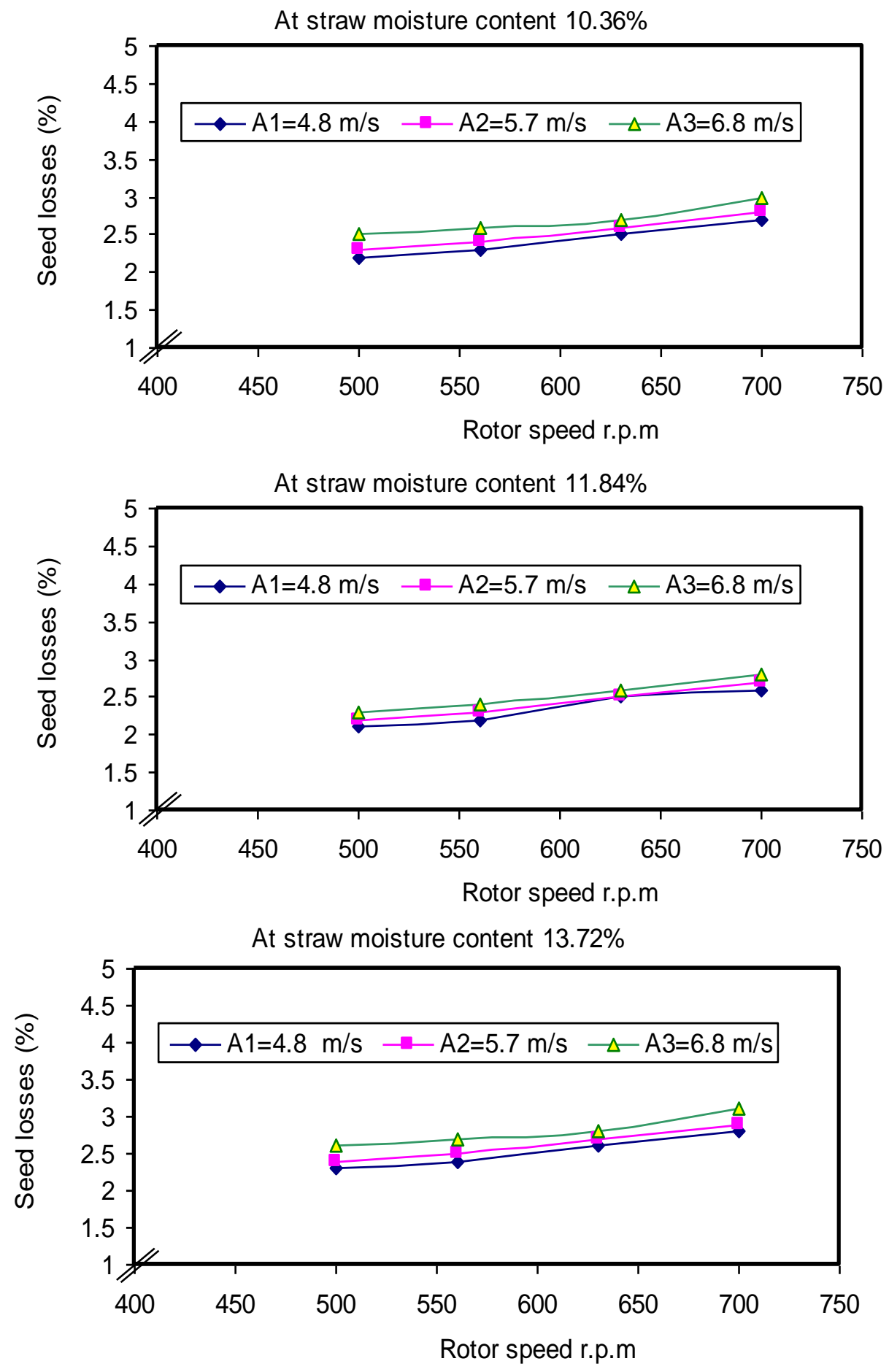

Fig.4. Effect of tested factors on seed losses. 


\section{Effect of tested factors on energy requirements ( $\mathrm{kW} . \mathrm{h} / \mathrm{ton})$ :}

Data presented in Table (1) shows the effect of rotor speed and air speed on the energy requirements as affected by test factors. Increasing rotor speed from 500 to $700 \mathrm{rpm}$ increased the energy consumed from 29.04 to $34.96 \mathrm{~kW} . \mathrm{h} / \mathrm{ton}$ at air speed $4.8 \mathrm{~m} / \mathrm{s}$ and straw moisture content $11.84 \%$. This may due to increased fuel consumption (Lit/h). While increasing air speed from 4.8 to $6.8 \mathrm{~m} / \mathrm{s}$ increased the energy consumption from 29.04 to $31.41 \mathrm{~kW} . \mathrm{h} /$ ton at rotor speed $500 \mathrm{rpm}$. This may be due to the increased rotor speed and air speed led to increase fuel consumption. Constant of productivity $0.540 \mathrm{ton} / \mathrm{h}$ may be due to using one feed rate.

Table 1: Effect of tested factors on required power and energy consumption requirements for threshing of caraway crop.

\begin{tabular}{|c|c|c|c|c|c|c|c|}
\hline \multirow{2}{*}{$\begin{array}{l}\text { Rotor speed } \\
\text { (rpm) }\end{array}$} & \multirow{2}{*}{$\begin{array}{l}\text { Productivity } \\
\text { (Ton/h) }\end{array}$} & \multicolumn{3}{|c|}{$\begin{array}{c}\text { Power consumed } \\
(\mathbf{k W})\end{array}$} & \multicolumn{3}{|c|}{$\begin{array}{c}\text { Energy consumed } \\
(\mathbf{k W} \cdot \mathbf{h} / \text { ton })\end{array}$} \\
\hline & & $S_{1}$ & $S_{2}$ & $\mathrm{~S}_{3}$ & $S_{1}$ & $\mathrm{~S}_{2}$ & $\mathrm{~S}_{3}$ \\
\hline & \multirow{4}{*}{0.540} & 15.68 & 16.32 & 16.96 & 29.04 & 30.22 & 31.41 \\
\hline 560 & & 16 & 16.64 & 17.28 & 29.63 & 30.81 & 32.00 \\
\hline 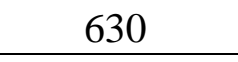 & & 17.6 & 18.84 & 18.56 & 32.59 & 33.77 & 34.37 \\
\hline 700 & & 18.88 & 19.2 & 20.84 & 34.96 & 35.56 & 37.92 \\
\hline
\end{tabular}

\section{CONCLUSION}

1. The results showed a promising attempt to provide the thresher with some modified parts to thresh caraway straw into seeds and chaff.

2. The optimum operating conditions of the developed thresher were found to be as follows:

Adjust thresher feed rate of $540 \mathrm{~kg} / \mathrm{h}$, using concave hole diameter 15 $\mathrm{mm}$, cleaning sieve hole diameter $3 \mathrm{~mm}$ and threshing forks angle $90^{0}$. Rotor speed of $500 \mathrm{rpm}$, air speed of $4.8 \mathrm{~m} / \mathrm{s}$ and straw moisture content of $11.84 \%$ are recommended to achieve caraway threshing into seeds and chaff at satisfied threshing efficiency of $73.7 \%$ and lowest seed losses of $2.2 \%$ and minimum required power of $15.68 \mathrm{~kW}$. It is recommended to conduct more research considering the results of the current study. Successful parts may be developed and finalized design may be ready to 
be attached to threshers to facilitate obtaining seeds suitable for commercial distributing.

\section{REFERENCES}

Awady, M. N., I. Yehia, M. T. Ebaid, and E. M. Arif, ( 2003 ). Development and theory of rice cleaner to reduce impurities and losses. Misr J. Agric. Eng., 20 ( 4 ): 53 - 68 .

Bansal, N. K. and Dahiya. B. S. (2001). Effect of threshing techniques on quality of sunflower seed. J of Indian Seed Research. 29(1): 5257.

Chandrakanthappa, Kammar, Batagurki, S. B. and Kammar. C. (2001). Evaluation of different threshing methods for primary processing of finger millet. Mysore J of Agric. Sci. 35(2): 128-132.

El-Behery A. A.; I. S. E. Yousef; S. A. F. El-Kady (2000) " Studies on flax threshing using a local paddy thresher" Egyptian J. of Agric. Res., Vol. 78 No. 1 pp. 489-497.

Embaby, A. T. (1985) "A comparison of different mechanization system for cereal crop production" M. Sc. Thesis, (Ag. Eng.,) Cairo Univ.

Johnson, R. (2003) " Setting threshers for harvesting best quality seed and field corn" Director, cooperative Extension service, Iowa state Univ. of science and Technology, Ames. Iowa, file: Engin.2-2.

Chandrakanthappa, Kammar, Batagurki, S. B. and Kammar. C. (2001). Evaluation of different threshing methods for primary processing of finger millet. Mysore J of Agric. Sci. 35(2): 128-132.

Metwalli, M.; M. M. Ismaeal and A. A. Nada(2003) " Energy consumption to harvest one ton of wheat in newly land" Misr J. Agric. Eng. 15-16 (3) pp. 867-876.

Omar, A. E. (1995).Mechanization of pea crop production .M. Sac. Thesis, Agric. Eng.Dept. Fac.of Agric., Zagazig Univ.

Tsujimoto T. and Sakurai (2006) "Research on the Development of Applicable Agricultural Machines for Small-scale Farmers in Africa (Part 2)-Case Study of Improvement and Trial-made of Turkish Thresher" Journal of the Japanese Society of Agricultural Machinery, VOL.68;NO.4;PAGE.65-71 


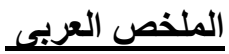

\section{تطوير وتقييم آلة ا لاراس المحلية لاراس محصول الكراويا}

\section{- جابر غمرى رضوان"* رضا جمعة سالم** - عبده شوقى العشرى"}

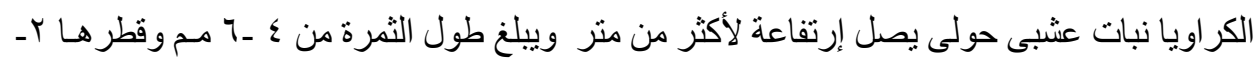

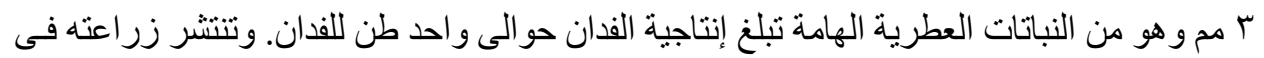

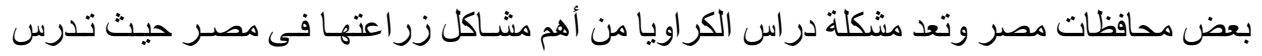

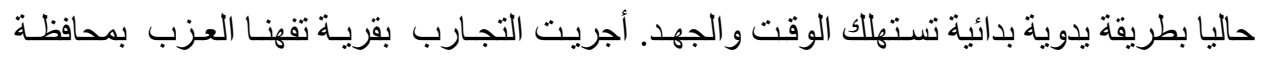

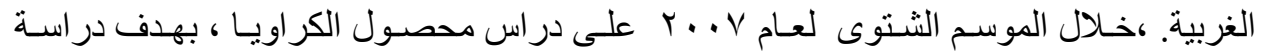

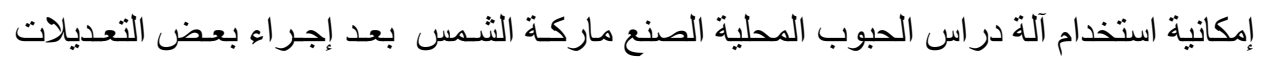

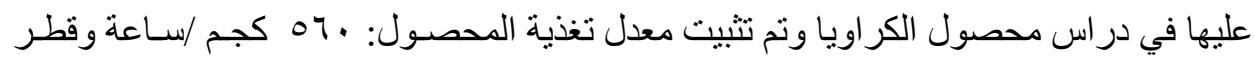
فتحات غر ابيل الفصل ب مم و خلوص صدر الدر اس 10 مم وز اويـة سـكاكين القطع مـع درفيـل

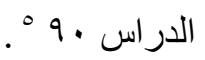
تحت العو امل المتغيرة التالية : الأن

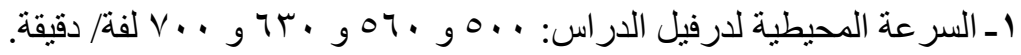

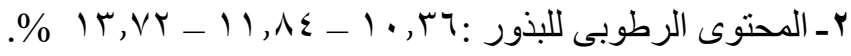

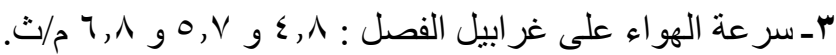

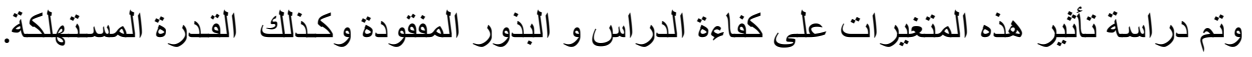

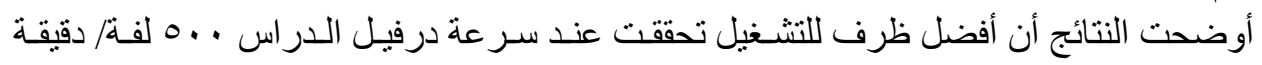

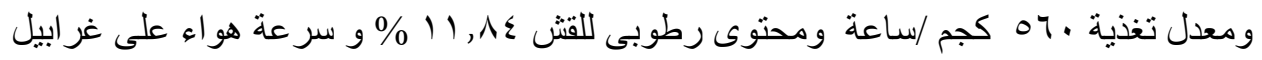

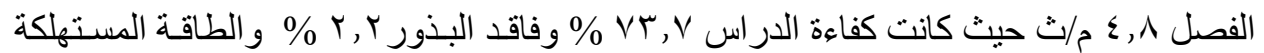

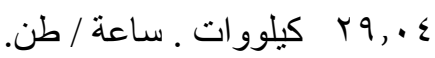

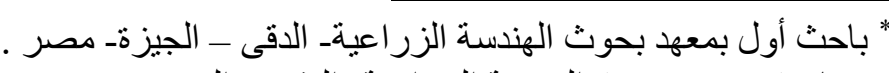

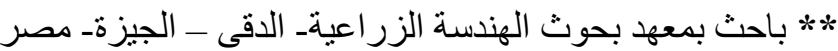

